\title{
THE PBGC's FLAT FEE SCHEDULE, MORAL HAZARD, AND PROMISED PENSION BENEFITS
}

\author{
Gregory R. NIEHAUS* \\ University of Michigan, Ann Arbor, MI 48109, USA
}

Received September 1987, final version received March 1989

The Pension Benefit Guarantee Corporation (PBGC) initially insured private pension benefits in exchange for a premium that was not risk sensitive. This paper derives conditions under which a moral hazard problem caused promised pension benefits to increase. The hypotheses are tested using data on individual pension contracts from the pre- and post-PBGC periods.

\section{Introduction}

In 1974 the U.S. Government established the Pension Benefit Guarantee Corporation (PBGC) to insure private pension benefits. ${ }^{1}$ Since that time, numerous proposals have appeared recommending that the PBGC's flat fee schedule be changed to reflect the risk of participants. ${ }^{2}$ Arguments against the flat fee schedule center on issues of moral hazard, adverse selection, and cross subsidization. This paper discusses these issues with a special emphasis on whether moral hazard caused a shift in employees' compensation toward higher promised pension benefits. ${ }^{3}$

Congress introduced several regulatory restrictions on the management of pension plans along with the PBGC insurance program. An important issue, addressed in this paper, is whether these regulations are sufficient to eliminate the moral hazard problems caused by the flat fee schedule. Fvidence on this issue may be relevant to other government insurance programs. For example, Buser, Chen and Kane (1981) and Flannery (1982) explicitly discuss the role of regulation in mitigating moral hazard problems

\footnotetext{
*The author appreciates the comments of two anonymous referees, Cliff Ball, Michael Bradley, Harry DeAngelo, Jim Little, Bill Marshall, Jay Ritter, Ted Snyder, Laura Starks and Adrian Tschoegl. Financial support from the Center for the Study of American Business at Washington University and the Michigan Summer Research Program are appreciated.

${ }^{1}$ The PBGC was established by the enactment of the Employee Retirement Income Security Act (ERISA).

${ }^{2}$ The 1988 budget changed the premium schedule to more closely reflect the risk of participants.

${ }^{3}$ For a general discussion of moral hazard, see Stiglitz (1983).
} 
with FDIC insurance. ${ }^{4}$ Other examples of government insurance programs that are likely to introduce moral hazard include government loan guarantees [see Chaney and Thakor (1985)] and subsidized flood insurance [see Kunreuther (1978)].

The paper proceeds as follows. In the next section, a brief description of the structure and regulation of private pensions is presented. In section 3 , the effect of the flat fee schedule on the behavior of sponsors of defined benefit plans is analyzed. The empirical results are presented in section 4 . A discussion of the results is contained in section 5 and a short summary concludes the paper.

\section{Description of the pension system}

This paper is concerned solely with corporate sponsored defined benefit plans. ${ }^{5}$ Prior to the passage of the Employee Retirement Income Security Act of 1974 (ERISA), corporate pension liabilities were not necessarily backed by the sponsoring firm's assets. If a sponsor terminated an underfunded plan, employees did not receive their entire promised benefit. Instead, they received only the benefits that could be paid from the pension fund. Although underfunded pension plan terminations usually occurred while a firm was reorganizing via bankruptcy, merger, spinoff, etcetera, a firm had the legal right to terminate an underfunded plan at any time. ${ }^{6}$

ERISA significantly changed the payoffs from underfunded pension plans. ${ }^{7}$ Sponsors are now liable for up to thirty percent of their net worth if an underfunded plan is terminated. Thus, ERISA forces firms to back pension liabilities with a portion of their non-pension assets. ERISA also established the Pension Benefit Guarantee Corporation (PBGC) to insure pension benefits. Initially, the PBGC charged the sponsors of all defined benefit plans the same annual fee of $\$ 1.00$ per employee. ${ }^{8}$ If a plan is terminated and the pension assets plus thirty percent of the sponsor's net worth is insufficient to pay all the promised pension benefits, then the PBGC will pay the benefits up to a maximum amount. Initially, the ceiling on

\footnotetext{
${ }^{4}$ See Goodman and Santomero (1986) and Ricart and Greenbaum (1984) for arguments against variable rate premiums for deposit insurance.

${ }^{5}$ Pension plans are of two basic types: defined benefit and defined contribution plans. Under a defined benefit plan, employees are promised a specific benefit when they retire. The promised pension benefit usually depends on the salary and the service of the employee. Under a defined contribution plan, the employer contributes a set amount of money to a fund on behalf of each employee. The employee receives the accumulated value of the fund at retirement.

${ }^{6}$ See the Legislative History of the Employee Retirement Income Security Act of 1974: Public Law 93-406 for reports on underfunded pension plan terminations prior to 1974.

'See Bulow. Scholes and Menell (1981). Ippolito (1986) and Logue (1979).

${ }^{8}$ The fee was increased in 1978 to $\$ 2.60$ and in 1987 to $\$ 8.50$ per employee. In 1988 , the per employee fee was increased to $\$ 16$ plus $\$ 6$ for every $\$ 1,000$ that vested benefits exceed pension assets per employee. However, the maximum fee is limited to $\$ 50$.
} 
guaranteed benefits was $\$ 750$ per month for each employee. ${ }^{9}$ In addition, the PBGC phases in the guarantee of benefit increases over a five year period. ERISA also restricts how a sponsor must fund its pension plan and allocate pension assets. The funding restrictions limit the extent to which a plan can become underfunded, and the asset allocation restrictions limit the risk of pension assets.

\section{Analysis of the flat fee}

Consider a firm with one employee prior to the introduction of the PBGC insurance. Suppose the employee is hired at the beginning of a period and retires at the end of the period. Let $\$ B$ be the pension benefit that the firm promises to pay the employee at the end of the period. Let $\$ A$ be the firm's contribution to the pension fund. This contribution is invested in a portfolio of assets and $\$ A_{1}$ is the random end-of-period value of the pension assets.

Now suppose the PBGC insurance is introduced, but that the firm does not change its compensation package, nor its financial management of the pension fund. In subsequent sections, the way in which the firm optimally adjusts to the PBGC's provisions is examined. If $A_{1}$ exceeds the promised benefit, $B$, then the benefit is paid and the sponsor receives the excess assets. ${ }^{10}$ If the pension assets are insufficient to pay the promised benefit, then the employee has claim to part of the sponsor's net worth. If thirty percent of the sponsor's net worth is not sufficient to pay the promised benefit, then the PBGC pays up to a maximum amount, $G$. Table 1 lists the payoffs to all the parties involved.

Modeling the payoffs in this way implies that the insurance sold by the PBGC is equivalent to a put option. The underlying asset of the option is the value of the pension fund's assets plus thirty percent of the net worth of the firm. The exercise price of the option depends on whether the level of promised benefits is greater or less than the level of guaranteed benefits. If promised benefits are less than guaranteed benefits, then the exercise price is the level of promised benefits. Otherwise, the exercise price is the level of guaranteed benefits. In exchange for the option, the sponsor pays the PBGC an annual fee of $\$ f$ per employee (initially, $f$ equalled $\$ 1.00$ ).

\subsection{Adverse selection and cross subsidization}

The introduction of the PBGC insurance increases the firm's cost of labor by the difference between the fee and the value of the put option: $(f-$ Put). As discussed above, the underlying asset of the put option is the pension

${ }^{9}$ The ceiling increases each year to reflect increases in the social security wage base.

${ }^{10}$ There is some debate over who owns excess pension assets. See Bulow and Scholes (1983). 
Table 1

End of period payoffs. ${ }^{a}$

\begin{tabular}{|c|c|c|c|}
\hline States & $\begin{array}{l}\text { Payoff } \\
\text { to sponsor }\end{array}$ & $\begin{array}{l}\text { Payoff } \\
\text { to employee }\end{array}$ & $\begin{array}{l}\text { Payoff } \\
\text { by PBGC }\end{array}$ \\
\hline$A_{1}>B$ & $N W_{1}+A_{1}-B$ & $B$ & 0 \\
\hline $\begin{array}{l}A_{1}<B \\
\stackrel{\&}{W} \\
0.3 N W+A_{1}>B\end{array}$ & $N W_{1}+A_{1}-B$ & $B$ & 0 \\
\hline $\begin{array}{l}A_{1}<B \\
\stackrel{\&}{\&} \\
0.3 N \underset{W}{W}+A_{1}<B \\
\stackrel{\&}{B<G}\end{array}$ & $0.7 N W_{1}$ & $B$ & $\left(0.3 N W_{1}+A_{1}\right)-B$ \\
\hline $\begin{array}{l}A_{1}<B \\
\quad \& \\
0.3 N W+A_{1}<B \\
\quad \& \\
B>G\end{array}$ & $0.7 N W_{1}$ & $G$ & $\left(0.3 N W_{1}+A_{1}\right)-G$ \\
\hline
\end{tabular}

assets plus thirty percent of the firm's net worth, $A+0.3 \mathrm{NW}$, and the exercise price is $\min (B, G)$. If $f>\mathrm{Put}$, then the PBGC insurance is equivalent to a tax on labor; otherwise, the insurance subsidizes the use of labor.

If the PBGC insurance program were voluntary, then a severe adverse selection problem would exist. Plans for which the value of the put option is less than the flat fee would not buy the insurance, leaving only the high risk plans in the program. As a result, the revenue received by the PBGC would be less than its expected losses. The PBGC insurance is mandatory, however, for all defined benefit plans. The mandatory nature of the program mitigates, but does not eliminate, adverse selection. A firm can select out of the program by terminating its defined benefit plan. A defined contribution plan or no plan at all could replace the defined benefit plan. ${ }^{11}$

\subsection{Moral hazard}

As discussed earlier, the introduction of the PBGC gives the firm a put

11 However, Tepper (1981) and Black (1980) show that tax benefits can be obtained from defined benefit (DB) plans that are not available to defined contribution (DC) plans. DR and DC plans also differ in their incentive effects and risk sharing [see Bodie, Marcus and Merton (1985), Kotlikoff and Wise (1984), and Lazear (1984)]. Finally, there are transaction costs associated with switching from a DB plan to a DC plan. 
option (the insurance) in exchange for a fee of $\$ f$. The difference between the insurance fee and the value of the insurance represents a subsidy or tax to the firm. In particular, the PBGC insurance reduces the firm's cost of labor by

$$
\text { Put }[A+0.3 N W, \min (G, B)]-f \text {, }
$$

where the first argument in Put [ , ] is the value of the underlying asset and the second argument is the exercise price of the option. Assume the put option can be valued as if it and the underlying asset were trading in a perfect market. This subsidy or tax, however, is not exogenous. Its value is affected by any of the firm's actions which alters the nature of the underiying asset or the exercise price of the put option. Sharpe (1976), Harrison and Sharpe (1983), and others examine the firm's incentive to alter its pension funding and pension asset allocation decisions. This paper concentrates on whether moral hazard exists with respect to the level of promised pension benefits, $\$ B$.

To incorporate ERISA's funding restrictions into the analysis, assume the sponsor's pension contribution, $A$, is proportional to $B$, with the proportionality factor fixed by funding regulations. ${ }^{12}$ Thus, the greater the level of promised benefits, the more the firm is required to contribute to the pension fund. In terms of the put option, the funding requirement implies that the initial value of the underlying asset depends on the level of promised benefits.

Consider first the case when promised benefits, $B$, exceed guaranteed benefits, $G$. In this case, an increase in promised benefits does not increase the PBGC's potential liability. However, because of funding restrictions, an increase in promised benefits increases the value of the assets backing the pension claims. In terms of the put option, the value of the underlying asset increases, but the exercise price remains constant. Thus, an increase in promised benefits decreases the value of the pension put which implies that the PBGC subsidy is reduced (or tax is increased). Consequently, moral hazard with respect to promised benefits does not arise when the pre-PBGC benefit is greater than the ceiling on guaranteed benefits. ${ }^{13}$

Now consider the case when promised benefits are less than guaranteed

\footnotetext{
${ }^{12}$ The actual funding restrictions state that a sponsor must fund the 'normal costs' of the plan and that 'unfunded past service liabilities' arising from plan amendments can be amortized over a thirty year period. The model imposes the restriction that both benefit accruals and benefits arising from plan amendments are subject to the same funding requirements. Thus, the funding assumption is actually more restrictive than what is allowed in practice.

${ }^{13}$ Moral hazard would arise, however, on other dimensions. For example, moral hazard with respect to the riskiness of pension assets would arise, because a firm would not bear the entire marginal cost of its decision to increase the risk of pension assets. Instead, part of this marginal cost would be borne by the PBGC.
} 
benefits. An increase in promised benefits increases the put option's exercise price and the value of the underlying asset. If the exercise price and the underlying asset increased by the same proportion, then the value of the put option would also increase proportionally. [See Merton (1974)]. When promised benefits increase, however, the proportional increase in the exercise price is at least as great as the proportional increase in the value of the underlying asset. Consequently, the value of the put option increases as promised benefits increase. ${ }^{14}$

Since the value of the put option increases, but the fee for the insurance does not increase, a firm can substitute promised benefits for other forms of compensation and decrease its cost of labor. Intuitively, in some states of the world the firm will not pay the additional promised benefits, yet it does not have to compensate the employee nor the PBGC for this additional risk. In summary, the PBGC insurance increases the marginal benefits of pension compensation when promised benefits are less than guaranteed benefits.

The incentive to increase promised pension compensation exists even for firms that are being taxed by the PBGC's fee schedule, because increasing the value of the put option reduces the tax. Thus, moral hazard affects both a firm for which the PBGC's insurance premium is greater than the value of the insurance and a firm for which the premium is less than the value of the insurance.

The magnitude of the moral hazard problem depends on the characteristics of the firm and its pension plan. For example, if the pension plan is considerably overfunded, then the pension put is out-of-the-money. Consequently, a change in promised benefits will have little effect on the put's value. This observation implies that, ceteris paribus, the moral hazard problem is related to the funding status of the pension fund. The more underfunded is the pension plan, the greater is the incentive to increase promised pension benefits.

Note that this analysis incorporates several restrictions imposed by ERISA that mitigate the moral hazard problem. In particular, the deductible equal to thirty percent of a firm's net worth, the ceiling on guaranteed benefits, and the funding restrictions all help mitigate the moral hazard problem. ERISA also imposed regulations that are not explicitly incorporated into the model. For example, the PBGC's guarantee of additional promised benefits is phased in over a five year period. In addition, ERISA gave the PBGC the right to terminate a pension plan before the PBGC becomes liable for underfunded benefits. The next section examines empirically whether, despite these restrictions, the moral hazard problem has altered the structure of employee compensation.

${ }^{14} \mathrm{~A}$ formal proof is available from the author. 


\section{Empirical tests}

\subsection{Data}

The empirical tests compare post-PBGC levels of promised benefits to prePBGC levels for individual pension plans. The 1970 and 1976-1978 Editions and supplements of the Digest of Selected Pension Plans, published by the Bureau of Labor Statistics, provide pension contract information for the preand post-PBGC periods. These data include benefit accrual formulae for 165 pension plans for the pre-PBGC period and 172 plans for the post-PBGC period. Both pre- and post-PBGC data are available for 129 plans.

Pension contracts specify promised pension benefits using a benefit formula. Two types of benefit formulae dominate the sample. A wage-based benefit formula specifies the monthly pension benefit as a percentage of wages. The percentage may be constant or it may depend on years of service with the employer. The relevant wage figure may be terminal earnings or an average of earnings over a specified time period. A service-based benefit formula specifies the monthly pension benefit as a dollar amount times years of service. For example, monthly benefits may equal ten dollars per year of service.

To control for inflation and changes in productivity over the sample period, the data are adjusted for changes in wage rates. If the pension benefit is specified in terms of a nominal dollar amount, the post-PBGC promised pension benefit is discounted by one plus the percentage change in the wage rate over the sample period. ${ }^{15}$ Because formulae that specify benefits as a percentage of wages are implicitly indexed to pre-retirement inflation and productivity changes, these formulae do not require adjustment.

For benefit formulae based on wages, the parameter of interest is the percentage that is applied to wages. For example, the pension plan for the tobacco workers at American Brands had the following pre-PBGC and postPBGC monthly benefit formulae:

$$
\begin{aligned}
& \text { pre-PBGC: Benefit }=0.01{ }^{*} \text { wages* }{ }^{*} \text { years of service, } \\
& \text { post-PBGC: Benefit }=0.0125^{*} \text { wages }^{*} \text { years of service. }
\end{aligned}
$$

Thus, the parameters of interest are 0.01 and 0.0125 . In this case, the benefits are recorded as having increased by $25 \%$.

For benefit formulae based on service, the parameter of interest is the promised monthly benefit per year of service. For example, the meat cutters at Armour Company had the following monthly benefit formulae:

\footnotetext{
${ }^{15}$ The wage index is for hourly compensation of persons in manufacturing. These data are published by the Bureau of Labor Statistics.
} 
pre-PBGC: $\quad$ Benefit $=\$ 5.00^{*}$ years of service,

post-PBGC: Benefit $=\$ 8.50^{*}$ years of service.

The parameters of interest are $\$ 5.00$ and $\$ 8.50$. Industrial wages increased $60 \%$ from the time the pre-PBGC formula was recorded to the time the postPBGC formula was recorded. Therefore, the $\$ 8.50$ figure is discounted by 1.60 , yielding a figure of $\$ 5.31$. In this case, benefits are recorded as having increased by $6.2 \%$.

The change in promised benefits could not objectively be determined in twenty of the 120 plans. For example, some firms changed from a service based benefit formula to an earnings based formula. Therefore, a comparison of the generosity of the two formulae requires assumptions about wage levels and years of service. Consequently, these twenty plans are eliminated from the sample. ${ }^{16}$

The pension plans are of three general types: single-employer plans that are collectively bargained, single-employer plans that are not collectively bargained, and multi-employer plans that are collectively bargained. The characteristics of collectively bargained plans are the result of negotiations between management and professional unions. A single-employer plan has only one sponsor. McDonnell-Douglas Corporation's plan for its machinists is an example of a collectively bargained single-employer plan. McDonnellDouglas Corporation's plan for salaried employees is an example of a noncollectively bargained single-employer plan. In contrast, a multi-employer plan has several sponsors. An example of a multi-employer plan is the pension plan for union carpenters in New York City, which has several contractors as sponsors.

\subsection{Hypotheses and results}

The analysis in section 3 predicts that promised benefits increased following the introduction of the PBGC insurance in 1974 if the additional benefits would have been covered by the insurance. There are two reasons why additional benefits would not have been covered by the insurance. First, the PBGC did not insure multi-employer plans until 1980. Second, even if the plan was covered by the insurance, if the pre-PBGC benefit level exceeded the guaranteed level, then additional benefits were not guaranteed. Thus, the data are divided into groups depending on whether additional benefits would have been covered by the PBGC insurance.

\footnotetext{
${ }^{16}$ The changes in the type of benefit formulae showed no obvious pattern.
} 


\subsubsection{PBGC insurance coverage}

Multi-employer plans were not covered by the PBGC insurance until 1980. Since the post-PBGC benefit formulae are from contracts written prior to 1980, multi-employer plans represent a control group. Thus, a comparison of multi-employer plans with single-employer plans controls for factors such as changes in the generosity of Social Security benefits, changes in effective tax rates, or changes in interest rates over the sample period. ${ }^{17}$

Among the single employer plans, those plans with promised benefits below the guaranteed ceiling need to be distinguished from those with promised benefits above the ceiling. The initial ceiling on guaranteed benefits was $\$ 750$ per month and the ceiling increased each year depending on the Social Security Wage Base. Aggregate data on monthly pension benefits suggest that the ceiling was not likely to be binding for most plans. For example, in 1984, ten years after the introduction of the PBGC insurance, the average monthly pension annuity was only $\$ 525$ [see Ippolito (1986)].

Pre-PBGC benefit levels for the plans in this sample were computed under several assumptions for earnings and service. The results of this exercise (not reported) indicate that very few (if any) of the single employer plans were likely to have had pre-PBGC benefit levels that exceeded the guaranteed ceiling. ${ }^{18}$ Thus, it is assumed that for all of the single employer plans, the guaranteed ceiling was not binding.

Consequently, a test of the moral hazard hypothesis involves a comparison of benefit changes between single-employer and multi-employer plans. Table 2 presents the data on this comparison.

The data are classified into one of three groups: Decrease Group, No Change Group, and Increase Group. The name of each group describes the change in promised benefits from the pre- to the post-PBGC period. Panel A of table 2 illustrates that the distribution of benefit changes differs across the two types of plans. Among single employer plans, $49 \%$ increased promised benefits and only $22 \%$ reduced promised benefits. In contrast, $36 \%$ of the multi-employer plans increased promised benefits and 52\% decreased promised benefits. A non-parametric chi-squared test rejects at the 0.01 level the hypothesis that the changes in promised benefits for single-employer and multi-employer plans are drawn from a homogeneous distribution. Thus, the data in panel $\mathrm{A}$ of table 2 support the moral hazard hypothesis.

Panel B of table 2 reports summary statistics on the percentage change in the benefit formulae for the two types of pension plans. Among the singleemployer plans, promised benefits increased on average by $7.8 \%$. In contrast, the mean percentage change for the multi-employer plans was minus $2.9 \%$.

\footnotetext{
${ }^{17}$ The methodology does not control for factors that affect promised benefits of singleemployer plans only or of multi-employer plans only. Theory about what these factors may be is presently lacking.

${ }^{18}$ Results are available from the author.
} 
Table 2

Percentage changes in promised pension benefits: Single-employer versus multi-employer plans."

\begin{tabular}{|c|c|c|}
\hline & Single-employer & Multi-employer \\
\hline & Abs. (rel.) freq. & Abs. (rel.) freq. \\
\hline \multicolumn{3}{|c|}{ Panel A: Frequency distribution } \\
\hline $\begin{array}{l}\text { Decrease } \\
\text { No change }^{\mathrm{b}} \\
\text { Increase }^{d}\end{array}$ & $\begin{array}{ll}17 & (22 \%) \\
22 & (29 \%) \\
37 & (49 \%)\end{array}$ & $\begin{aligned} 17 & (52 \%) \\
4 & (12 \%) \\
12 & (36 \%)\end{aligned}$ \\
\hline \multirow[t]{2}{*}{ Total } & $76(100 \%)$ & $33(100 \%)$ \\
\hline & Single-employer & Multi-employer \\
\hline \multicolumn{3}{|c|}{ Panel B: Sample statistics } \\
\hline $\begin{array}{l}\text { Mean } \\
\text { Standard } \\
\text { deviation } \\
\text { Number of } \\
\text { observations }\end{array}$ & 0.078 & $\begin{array}{l}0.242 \\
33\end{array}$ \\
\hline $\begin{array}{l}t \text {-statistic for } \\
H_{0}: \text { mean }=0\end{array}$ & 3.38 & -0.68 \\
\hline \multicolumn{3}{|c|}{$\begin{array}{l}\text { "Source: The } 1970 \text { and } 1976 \text { Digest of Selected Pension Plans, } \\
\text { published by the Bureau of Labor Statistics. } \\
\text { 'Decrease indicates that the promised pension benefits decreased } \\
\text { over the sample period. } \\
\text { 'No change indicates that the promised pension benefits did not } \\
\text { change over the sample period. } \\
\text { dIncrease indicates that the promised pension benefits increased } \\
\text { over the sample period. }\end{array}$} \\
\hline
\end{tabular}

The final row of panel B reports the results of a one-sided $t$-test. The null hypothesis is that the percentage change in promised benefits is equal to zero. The alternative hypothesis is that the percentage change in promised benefits is greater than zero. The null hypothesis is rejected for singleemployer plans, but not for mult-employer plans. Thus, a comparison of single employer plans with multi-employer plans provides substantial evidence that the plans covered by the PBGC insurance increased promised pension benefits relative to those plans that were not covered by the insurance.

\subsubsection{Funding status}

The moral hazard hypothesis also predicts that the increase in promised benefits would be greater the less well funded the plan. Measuring the funding status of the pension plans in the sample is problematic because corporations typically sponsor several different pension plans. For example, a manufacturing firm is likely to establish separate plans for salaried workers, 
Table 3

Percentage changes in promised pension benefits: Single employer plans: Collectively bargained versus non-collectively bargained plans. $^{2}$

\begin{tabular}{|c|c|c|}
\hline & \multicolumn{2}{|l|}{ Single employer } \\
\hline & $\begin{array}{l}\text { Collectively } \\
\text { bargained }\end{array}$ & $\begin{array}{l}\text { Non-collectively } \\
\text { bargained }\end{array}$ \\
\hline & Abs. (rel.) freq. & Abs. (rel.) freq. \\
\hline \multicolumn{3}{|c|}{ Panel A: Frequency distribution } \\
\hline $\begin{array}{l}\text { Decrease } \\
\text { No change } \\
\text { Increase }\end{array}$ & $\begin{array}{rr}13 & (30 \%) \\
4 & (9 \%) \\
27 & (61 \%)\end{array}$ & $\begin{aligned} 4 & (13 \%) \\
18 & (56 \%) \\
10 & (31 \%)\end{aligned}$ \\
\hline \multirow[t]{3}{*}{ Total } & $44(100 \%)$ & $32(100 \%)$ \\
\hline & \multicolumn{2}{|c|}{ Single employer } \\
\hline & $\begin{array}{l}\text { Collectively } \\
\text { bargained }\end{array}$ & $\begin{array}{l}\text { Non-collectively } \\
\text { bargained }\end{array}$ \\
\hline \multicolumn{3}{|c|}{ Panel B: Sample statistics } \\
\hline \multirow{3}{*}{$\begin{array}{l}\text { Mean } \\
\text { Standard } \\
\text { deviation } \\
\text { Number of } \\
\text { observations } \\
\text { t-statistic for } \\
H_{0}: \text { mean }=0\end{array}$} & $\begin{array}{l}0.101 \\
0.238\end{array}$ & $\begin{array}{l}0.046 \\
0.121\end{array}$ \\
\hline & 44 & 32 \\
\hline & 2.79 & 2.15 \\
\hline
\end{tabular}

clerical workers, assembly line workers, etc. Although data are available on the aggregate funding status of a firm's pension plans, the funding status of individual pension plans is not publicly available. As a result, the relationship between funding status and promised benefit changes cannot be examined in detail.

Some insight into the effect of funding status on promised benefit changes can be obtained, however, because the funding status of collectively bargained and non-collectively hargained plans differ, on average. Pre-ERISA funding levels for plans covering union workers were thirty percent lower than for non-union plans [see Ippolito (1985)]. Thus, among the single employer plans, collectively bargained plans are expected to show a greater increase in promised benefits than non-collectively bargained plans.

Table 3 provides a comparison of collectively bargained and noncollectively bargained plans. Panel A reports that the percentage of firms that increased promised benefits is significantly greater for collectively bargained plans than for non-collectively bargained plans. In particular, a nonparametric chi-square test rejects that the two groups are drawn from a homogeneous distribution. 
The evidence in panel B of table 3, however, is less supportive of the hypothesis. Although the mean percentage change for collectively bargained plans is greater than for non-collectively bargained plans, the difference in means is not significant at conventional levels.

\section{Discussion of results}

The results of the previous section indicate that promised pension benefits increased in single-employer plans following ERISA. This evidence is consistent with the hypothesis that the PBGC's flat fee schedule causes a moral hazard problem with respect to promised pension benefits.

The results are also consistent with two other hypotheses about the PBGC. The first hypothesis is that the PBGC reduced the costs of negotiating and enforcing pension contracts. According to this argument, severe contracting problems existed prior to the formation of the PBGC, and the PBGC significantly reduced these problems. Ippolito (1988) thoroughly examines the validity of this alternative explanation. He finds no evidence that severe contracting problems existed prior to ERISA or that the contracting environment changed following ERISA.

The second alternative hypothesis is that the PBGC insurance causes a more efficient sharing of pension risk. According to this argument, the introduction of insurance shifts risk away from employees and employers to the more efficient risk bearer, the PBGC. As a consequence, the risky activity (i.e., pension compensation) is encouraged. Note that according to this argument, promised benefits would have increased even if the insurance were fairly priced.

It is difficult to distinguish the moral hazard hypothesis from the risk sharing hypothesis using the data presented here. Both hypotheses predict that promised benefits would increase in plans covered by the insurance, and both predict that the increase would be higher in riskier plans (i.e., more under-funded plans). Thus the increase in promised benefits documented earlier may be partially attributed to risk shifting.

A question naturally arises about the risk sharing argument: If fairly priced insurance would increase pension compensation, then why did employers and employees not purchase insurance in the private market? One possibility is that a market failure occurred for pension insurance, perhaps because of the systematic risk associated with pensions [see Campbell and Glenn (1985)]. However, private insurance is available for pensions. A second possible answer to why private insurance was not purchased is that risky pensions were the efficient form of compensation. ${ }^{19}$ In this case, the PBGC insurance interferes with efficient contracting between employees and employers.

\footnotetext{
${ }^{19}$ Ippolito (1985) argues that risky pensions act as a bond to prevent unions from "holding up' the firm and extracting rents.
} 


\section{Summary}

This paper derives the hypothesis that promised pension compensation increased following ERISA in plans that were covered by the PBGC insurance program. This hypothesis is based on the argument that the PBGC's flat fee schedule causes a moral hazard problem with respect to promised pension compensation.

The empirical evidence supports the hypothesis that moral hazard induced firms to increase promised pension compensation after the introduction of the PBGC insurance. Plans that were affected by the PBGC insurance show a significant increase in promised benefits relative to plans that were not covered by the insurance. Of the plans covered by the insurance, those that were the result of collective bargaining show a greater increase (although not statistically significant) in promised benefits than non-collectively bargained plans. Since, on average, collectively bargained plans are less well funded than non-collectively bargained plans, the latter evidence lends additional support to the moral hazard hypothesis.

\section{References}

Analysis of single employer pension plan terminations, 1977, The Pension Benefit Guarantee Corporation, Publication no. PBGC 507 (Washington, DC).

Black, F., 1980, The tax consequences of long-run pension policy, Financial Analysts Journal, July-Aug., 25-31.

Bodie, Z., A. Marcus and R. Merton, 1985, Defined benefit versus defined contribution plans: What are the real tradeoffs? Working paper no. 1719 (National Bureau of Economic Research).

Bulow, J. and M. Scholes, 1983, Who owns the assets in a defined benefit pension plan, in: $Z$. Bodie and J. Shoven, eds., Financial aspects of the United States pension system (University of Chicago Press, Chicago, IL) 17-36.

Bulow, J., M. Scholes and P. Menell, 1981, Economic implications of ERISA, in: Z. Bodie and J. Shoven, eds., Financial aspects of the United States pension system (University of Chicago Press, Chicago, IL) 37-56.

Buser, S., A. Chen and E. Kane, 1981, Federal deposit insurance, regulatory policy, and optimal bank capital, Journal of Finance, March, 51-60.

Cambell, T. and D. Glenn, 1984, Deposit insurance in a deregulated environment, Journal of Finance, July, 775-787.

Chaney, P.K. and A.V. Thakor, 1985, Incentive effects of benevolent intervention: The case of government loan guarantees, Journal of Public Economics 26, 169-189.

Corporate pension plan study: A guide for the 1980s, 1980 (Bankers Trust Company, New York).

Flannery, M., 1982, Deposit insurance creates a need for bank regulation, Business Review, Jan./Feb. (Federal Reserve Bank of Philadelphia, Philadelphia, PA).

Goodman, L. and A. Santomero, 1986, Variable-rate deposit insurance: A re-examination, Journal of Banking and Finance 10, 203-218.

Harrison, J.M. and W. Sharpe, 1983, Optimal funding and asset allocation rules for defined benefit pension plans, in: Z. Bodie and J. Shoven, eds., Financial aspects of the United States pension system (University of Chicago Press, Chicago, IL).

Ippolito, R., 1985, The economic function of underfunded pension plans, Journal of Law and Economics, Oct., 611-651. 
Ippolito, R., 1986, Pensions, economics and public policy, Pension Research Council (Dow Jones-Irwin, Homewood, IL).

Ippolito, R., 1988, A study of the regulatory impact of ERISA, Journal of Law Economics, forthcoming.

Kotlikoff, L. and D. Wise, 1984, The incentive effects of private pension plans, Working paper no. 1510 (National Bureau of Economic Research).

Kunreuther, H., 1978, Disaster insurance protection: Public policy lessons (Wiley, New York).

Lazear, E., 1984, Incentive effects of pensions, Working paper no. 1126, National Bureau of Economic Research, Inc., May.

Ledolter, J. and M. Power, 1984, A study of ERISA's impact on private retirement plan growth, Journal of Risk and Insurance, June, 225-243.

Legislative History of the Employee Retirement Income Security Act of 1974: Public Law 93405, 1976, prepared by the Subcommittee on Labor of the Committee on Labor and Public Welfare, United States Senate (U.S. Government Printing Office, Washington, DC).

Logue, D., 1979, Legislative influence on corporate pension plans (American Enterprise Institute for Public Policy Research, Washington DC).

Merton, R., 1973, Theory of rational option pricing, Bell Journal of Economics and Management Science, 4, Spring, 141-183.

Mumy, G., 1984, The role of taxes and social security in determining the structure of wages and pensions, Journal of Political Economy 19, 574-585.

Ricart, J. and S. Greenbaum, 1984, Pricing deposit insurance: An apologia, Research paper no. 99 (Institute de Estudios Superiores de la Empresa).

Sharpe, W. F., 1976, Corporate pension funding policy, Journal of Financial Economics 3, June, 183-194.

Stiglitz, J., 1983, Risk, incentives and insurance: The pure theory of moral hazard, the Geneva Papers on Risk and Insurance 8, 4-33.

Tepper, 1., 1981, Taxation and corporate pension policy, Journal of Finance 36, March, 1-13. 